\title{
ELECTRON MICROSCOPIC STUDIES ON THE ORIGIN OF CHOLESTERINE CRYSTAL IN THE CHOLESTERINE GRANULOMA (IN HUMAN EARS)
}

\author{
TAKESHI SAKAMOTO \\ Department of Otolaryngology, Faculty of Medicine, \\ Hokkaido University, Sapporo (Director: S. Hirano, M.D.)
}

Cholesterine granuloma obtained from the mastoid cavities of ten operated patients aged from 12 to 56 years was fixed by Millonig's $1 \%$ osmic solution, immediately after removal, embedded in Epon 812, stained by uranyl acetate solution and electron-microscopically observed in order to study the origin of cholesterine crystal which is recognized as cholesterine cleft within the granuloma.

Results obtained were as follows:

1. Small cholesterine clefts (possibly in early stage of development) were seen to be surrounded by numerous degenerated erythrocytes, D.Cell (see below) and phagocytes being in a close contact with each other (Fig. 6, 7).

Several phagocytes in which phagosome, residual bodies and myelin figures indicated their active function, including the small cleft also (Fig. 6,7).

2. Foam cells contain various sized and forms of vacuoles and granules were often seen around the clefts. Some of the cells contained small cholesterine clefts or phagosomes in the cytoplasma. These cells were therefore, supposed to belong to phagocytes (Fig. 1,2).

3. Erythrocytes and degenerated cells were always. found to be in a close contact with cholesterine cleft at its surface. The former degenerated freguently. The size of the latter was equal to that of the former. It had a cell membrane, but lacked nucleus. The cytoplasma consisted of diffusely scattered fine granules of low electron density.

The feature of the cell suggested that the degenerated blood cell was its origin. Thus the cell was called D-cell by the author.

4. Vascular lesions, such as stasis and thrombosis were frequently observed in the vicinity of the clefts (Fig. 4).

5. These findings strongly suggested that the cholesterine crystal derived from blood-element which had emigrated from disturbed blood vessels and could develop within extracellular spaces and that it could grow within phagocytes.

\section{ヒトの耳に生じるコレステリン肉芽腫のコレステリン 結晶発生機序に関する電子顕微鏡的研究}

\author{
北海道大学医学部耳鼠咽喉科教室（主任：平野新治教授）

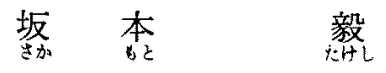

\section{緒言}

最近，多数の報告がみられるよらになったヒトの耳に 生じるコレステリン肉苏腫は，青色鼓膜を有する患者の 他は，慢性中耳炎の手術時に偶然発見することが多い， しかし，その成因は不明であり，成因を耳管閉塞 ${ }^{112), ~}$ 血管血流の異常311 ，炎症性産物の機化に求的るものも
あり ${ }^{(5 / 6) 7 / 8)}$ 確定的なものはない. 又, 実驗的に動物に二 レステリン肉芽尰をつくることが難しいため, その成团 の追求を困難にしている.

コレステリン肉芽腫内のコレステリン結晶の由来につ いても，側頭骨含気腔粘膜上皮の脂肪変性の結果生しる といらもの”, 中耳腔内の出血に由来するといらもの゙ 
33410011)があるが確定的なものはない．

今回, 著者はヒトの耳に生ビたコレステリン肉芽婳内 のコレステリン結晶の発生機序を，電子顕微鏡的に解明 しょうと試みた。

\section{研究材料ならびに方法}

材料は当院に入院した満12才より56才に至る男女 10 人、11耳の乳乫腔にみられた手術材料を用いた。

手術は，すべて0. $2 \%$ T-caine による局所麻酷を施行 し, 麻酔部位は乳突部, 外耳道にとどめ, 乳突腔一の麻 酸郕の影響をさけた，乳突部削開と同時に肉泺腫を速や 加に耳内錐子にて採取, 直ちに $5^{\circ} \mathrm{C}$ 以下に冷保存した Millonig 法による $1 \%$ オスミック酸に固定, 厚さ $2 \mathrm{~mm}$ 以下に紐切儿同固定液で 2 時間半固定, その後水洗する ことなく50\%アセトンより始まるアセトン上昇列と 100 \%アセトンで合計 2 時間半脱水し, Luft 法 ${ }^{12)} に$ 準じて Epon 812 に包埋した，包埋剤の硬さの調節には，A，B 液を5：5の割合に混合したものを使用した。超薄切片の 作製は LKB 4800型ミクロトームを使用しガラスナイフ にて行なった。ついで醋酸ウラニールによる単染色を行 なって, 明石 TRS-50 EI 型, および日立 HS-7D 型電 子影徽鏡（以下，電顕という）によって観察し，直接倍 率2000倍より10000倍にふたり撮影した。 な执，超薄切 片を切る前後に同一電影用包埋試料加ら 約 $0.5 \mu \sim 0.1 \mu$ の切片を作り, アルカリトルイジンブルー13)で染色し光 学䫓微鏡 (以下, 光㪟という) 的検索を行なった。

\section{所見}

コレステリン肉芽腫（以下，肉芽腫といら）内のコレ ステリン結晶（以下，コ結晶という）はオスミック酸で は固定されず，アセトン上昇列による脱水操作で容易に 溶解しアアルコール上昇列の脱水操作を行なった光顕所 見と同しく抜け凯となり，附図にみるごとく，いわゆる コレステリンクレフト（コレステリン裂嘹，以下，コ・ クレフトといら）となり，ネガティブ像が観察される.

コ・クレフトは，大体長方形の四隅の角が丸みをもっ た形としてあらわれることが多い大小は一定せず，小さ いものは $2 \mu \times 0.25 \mu$ ，大きいものは $500 \mu \times 2.5 \mu$ 以上に 達するものもある、コ・クレフトの周囲は完全に膜様構 造によってとり囲生れている場合と，一部が断裂消失す る場合とがある(写真 1$)$.この膜様構造をみる場合、こ れがクレフトに接する細胞の細胞膜の延長か，細胞内の 膜性小器官の膜であるか決定できないことが多かった。

以下,クレフトに接する頻度の多い細胞, および周困 にみられた血管について記述する。
巨細胞：クレフトの周囲には細胞膜の境界なしに核が 数個並列寸る像をしばしば認める，細胞貎には会食顆粒 を認め, mitochondria は比較的に少なく, endoplasmic reticulum が偏在して発達する傾向がある. endoplasmic reticulum が抬張し泡洙細胞への移行像を示寸場合も多 く認められる(写真2)。

泡洙細胞：種々の大きさであらわれてくる，核の偏在 をみることが多い（写真 1 ）。空胞は胞体をほとんど充 满している。空胞の形は丸いものが多いが，不規則な形 であらわれるものもある（写真8，9）。空胞の大きさ は不同である。空胞は限界膜を有し，その内容は電子密 度の低い系状物が散在したようになってみえることが多 い. 空胞間に電子密度の高い大小種々の円形の顆粒が多 数散在する. 空胞の大きさが極端に異なり，かつ偏在す ることもある．胞体内にphagosome，少さいコ・クレフ 卜を有するるのもある（写真 2）。

$\mathrm{D}$ 細胞：赤血球と共にコ・クレフトの周辺，またはこ れと密接してほとんど常在する細胞である.大きさは赫 血球と略々同大で，核を認めず，細胞質は砂粒をまき散 らしたような電子密度の低い粒子群よりなる。この粒子 群の他に，小空胞，電子密度の高、微細な顆粒をすずか に有するものもある(写真 6 ).コ・クレフトがこの細 胞に挾まれた形上なってあらわれる場合がしばしばみら れる(写真 3 )。これらの稩胞を仮りにD細胞と名づけ た.

血管外赤血球：光顕所見でも赤血球がコ肉芽胛の血管 外に多くあらわれ，これらはしばしば変性しエオジンに 淡く染まって認めら机る。電顯的に観察すると,コ・ク レフトの周边, またはこれに密接して常在する赤血球 は，色々な形であらわれ，かつ電子密度に差を生じて認 められる(写真 $3,5 ， 6 ， 7 ， 8 ， 9$ ).

変性細胞：D細胞もこれに属するが，变性細胞はとく にコ・クレフトが大きく，かつ多数存在する視野に多く 認められる。濃縮した核を認めることもあるが，核の存 在が認められないことが多く、紐胞質の内容は砂粒を散 在したような電子密度の低い粒子群よりなることが多 $\checkmark$.

血管：コ・クレフトの周辺には, しばしば血流停滞, ないしは血栓像を示す血管が認められる。すなわち，管 腔内に赤血球, 栓球, 他の血液細胞, および血獎成分が つまっている像がみられ，血管の内皮細胞は， tight junction 境として隣接する内皮間に電子密度の差を生じ ている (写真 4 , 久印で示寸)，また，電子密度の低い 
明るい血管内皮細胞上電子密度の高い暗い内皮細胞上が 血管腔を形式し，かつ血流停滞を示す像も認められた。 また pericyte に脂質とみられる顆粒を多く有する血管 の所見もしばしば認められた。

さらに，光顐的には明確にコ・クレフトとして識別で きないような，小さいコ・クレフトを検索して得た所見 は次のごレくである。

1) 細胞外にコ・クレフトを認め,このコ・クレフトは 数多くの赤血球とD細胞とに囲まれ，その間償は電子 密度の低、微粓子叞によって埋められている，そのす ぐ周辺には数多くの myelin figure 拉よび residual body を有する大きな食細胞を認める(写真 5 ).

2）細胞外に多角形となったコ・タレフトを認め，この クレフトは多数の赤血球, $\mathrm{D}$ 細胞, 泡沫細胞, および 単球㥞細胞によって囲まれており，これらの間隚は微 細な低い電子密度の粒子群によって埋められている。 これらの赤血球の電子密度には明らかに差が認められ る(写真 8,9$)$.

3）上述の2)の所見を示す視野に粼接して，種々なる電 子密度有する赤血球，D細胞，および食細胞に囲ま れ，細胞外にコ・クレフトが認められる。食細胞は赤 血球の 4 10倍の大きさで, 多くの myelin figure, residual body，および phagosome を有する。この食 細胞の一つに小なコ・クレフト走認める（写真 6 , 7 ).

\section{総括ならびに考按}

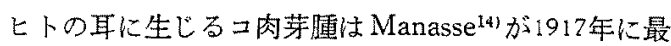
初に報告したといわれるが，その後次第に報告が堌加し てきている゙ー11!。しかし，その成因は不明な点が多い。

二肉芽遁をつくる動物奏験は Friedmann ${ }^{(3)}$ ：および教 室の土田等河によって報告されているのみである。すな わちFriedmann ${ }^{63}$ はモルモットの耳に, 純アルコール・ エーデ等分液にコレステリン結晶を浮游させた液を注 入してコ肉芽属をつくったが, 果して注入したコレステ リンによって生じたすのか，エーテル・アルコールによ る刺激で生じたものか不明である。土田等は1\%苳酸を 週 1 回，5〜20回家乘の耳に注入してコ肉芽缠索つく り，炎症によってコ肉芽腫が生じることを立証し，さら

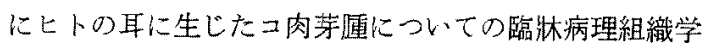
的検索成績とあわせ考察し，二肉芽腫は慢性中耳㷋によ って中耳腟に生じた肉芽嗹が，その吸收途上に血行障码

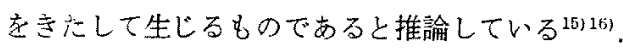

しかし，コ肉芽鋌內のコ結晶の由来については，中耳
腔内に生じた血液に由来するといら意見(3)10177 が多い が，確定的なものではなく，かつこれに反対する意見引 もある。

これら上述のコ肉茅連に関する報告をみると, コ結晶 とその週辺の関連性を組織学的に追求した報告は見当ら ない，著者は，コ結晶とその周辺との関連性を明確に観 察すれば，二結晶の発生機序を知りらると考えた。

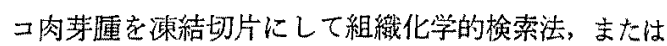
重屈折法を用いて観察すると, ユ結晶自体の検出は可能 であるが，ての周辺との関连性を明確につかむことはで きない，普通標本ではアルコール等による脱水操作中 に，コ結晶は溶解して抜け殼（すなわちコ・クレフトで あるが）上なる：この埸合、ニ・クレフトの周辺は観察 できるが，光顕の分解能の許容する範囲内の観察にとど まる。

著者注，コ結晶とその周边との関連性を明碓に知り， コ結晶発生機序のいとぐちを形態学的につかものに，す ぐれた分解能をもつ電顕が応用できないかと考えた。

電䫘標本を作製する際，固定刜として一般に用いられ ているオスミック酸は，コ結晶を除くほとんどすべての 脂僙を固定することが知られているが潘，Millonig法に 上る $1 \%$ オスミック酸溶液中でコ結晶の形が変わるか否 かを知るため，市販のコ結昆を同液に3時間浸漬してみ たが，その結晶形は不変であった。

次いでこの結晶を50\%加ら始まるアセトン上昇列に入 れると速やかに溶解した。したがって，肉芽腄を上述 した方法で固定・脱水を行なえばコ肉芽腫内のコ結晶は アセトン溶液内に溶出してしまうが，コ結晶の形はコ肉 芽腫にネガティブ像となって，略々そのままの形友残し うると考えた。つまりこのネガティブ像を電顕的に追 及することによって，コ・クレフトとその周辺の関連性 を, 光顕の観察よりはる加に明確にとらえうると考え た.

コ肉芽尰内に二結晶が発生してくる場合を考えると， はじめから大きい結晶となってあらわれてくるとは考え 難けので, コ結晶のあらわれてくる初期像をとらえるに は，小さいコ・クレフトを追及していく必要があると考 え，小さいクレフトの存在する視野を選んで観察をすす めた。

以下, コ・クレフトとその周迎を観察してえられた所 胃意考察する。

1) 血管の変化

光影的なコ肉芽腫の組織検密の報告では，コ肉芽腫 
内、またはその周辺の血管の変化に関するむのは甚だ少 ない，二肉芽隀内の毛細血管に多核白血球のつまってい

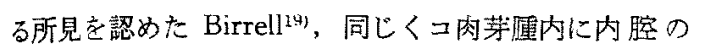
閉塞した血管を多数認めた Lichtenstein ${ }^{201}$ ，コ肉街腄と その周辺に血管腫, または静脈瘤の存在を考えた Johnston $^{3)}$ の論文をみるに過ぎない.土田䄈は有茎性しなっ た二肉苏嗹の荃部の血管が，その周斗にのびてきた上皮 に絞扼さ机た所見を報告し，二肉芽腫が血行障䅞に宿ち 入っていることる指摘している。

電顕的にコ肉芽畽内の血管の変化を観察報告したもの はないが，著者はコ・クレフトの周辺で紐静脈の血桎 像, ないしは血流停滞像をしばしば認めた（写真4）。 この血管には一個の赤血球，数個の柽球，他の血 液 細 胞および血䇰成分がっまってみられ，この血管の tight junction 党境亡する㴹接の 2 個の内皮間に電子密度の差 を生していることが認められた。この内皮間の電子密度 の差につけては，血管に炎症等の病変を生じている時に あらわれるといら見解到と， posteapillary venuleにみ られる正常な所見であるとい5見解”2があって，その意 義は不明である。この拖, 血䈏の pericyteの胞体内に脂 質とみられる顆粒が多くみられる所見もしばしば認めた がこれが変性を示しているものか，賁食された脂質を 示している像であるか注明確にできなかった。

2）泡沫細胞について

この細胞は動脈硬化，黄色腫などの脂質代謝異常をみ る葴器・器官に多くあらわれることがしられている181231 24)、しかしながら，コ肉芽腫内にあらわれる泡沫細胞に ついては, Birrell193がコ・クレフト間にこの細胞群をみ たという簡単な記裁をみるのみである、元来, この細胞 については定義がはっきりせず，その起源についても血 管内皮細胞, 線維細胞, 網内采内皮細胞, 平滑笳和胞等

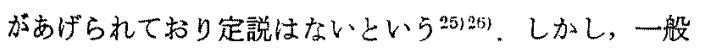
に注常在組織成分である細胞が食作用をあらかしたもの であるとい5見方"们が有力である。

著者のとらえた泡沫細胞は phagosome を有し，また 小さなコ・クレフトを胞体内に有し泡沫細胞への移行を 示すむのもあったことより，この細胞は食細胞の一種と 考えるのが妥当である。したがってこの細胞は，コレス テリンを異物として処理しょうとしてあらわれた食細胞 の一つであると考える。

3）赤血球拉よび細胞について

コ肉芽腫内の血管外に赤血球がしばしば多数みられる こと、およびこの組織にへモジデリンの沈着をみること
は光顕的によく知られている。これらの所見が, コ肉第 陑のコ結晶は血液に由来するといら見解の根扰の一つに なっている、しかしながら, 著者のとらえたコ・タレフ トならびにD練胞が密接な関俕に放る所見（写真3，5， 6，7，8，9）玨，電顕を使用してはじめてとら机像で ある、とくに写真 3 にるD細胞と小さいコ・タレフト が、か子合方形となり，しかも二の接するD細胞の辺縁 が臌化してみえる所見は，コ結晶がD細胞由来ではない か上いら可能性堂考えさせる。D細胞は赤血球とほとん ど同時にあらわれること，その形状，大きさ，細胞翼が 略々均一なこ上，および核が認められないことより赤血 球由来であることを強く示唆しているが，この二つの細 胞閒の移行像とみられる紐胞をこらえてないので決定は 現在の段階ではできない。

4) 二結晶発生の切期起示与と若えられる所見につい $\tau$

亦血球の直径より小さいコ・クレフトは, 亦血球, ま たはD細胞と密接して常在すること（写真 $3 ， 5$ ) から も，二結晶が血液成分由来であること強く示唆する が, コ・タレフトが多数の電子密度の異なる赤血球に囲 ま机て存在し，その間隐が低い電子密度の粒子群によっ て埋められており，加之の周四には赤血球，またはD 細胞以外に強い変性を示す細胞がみら九ないことから， この粒子群が血慗成分を示す可能性は強い。これは一 層, 二結晶が血液成分由来であるといら見解を支持する と考える(写真8)。この所見宗正視野につういて， 小さいコ・クレフトが細胞外に存在し，このクレフトを 多数の電子密度の異なる赤血球, D細胞, 食細胞がとり 圈み，かつ，食細胞の胞体内に小さなコ・クレフトが存 在する視野をしらた（写真 7$)$ ）この所見江血液成分 よりコレステリンが生じ，これが組織間隚でコ結晶とな って析出し，他方で住食細胞に䌸食されその胞体内に二 結晶となって析出したとみられる。このことは，血液成 分が血管外に游出して貯留寸る程，コレステリンが増加 し, 組織間吵の二楛晶は成長して大きくなり，また，二 レステリンの貪食がすすめば，食細胞内の二結晶も成唇 し大きくなっていくと考えられる，血管外に血液成分が 游出して吸収されずに䝪溜する現象の発現には, postcapillary venule の血行障㥂がーつの誘因になりらる上考 える.

周知のよ5に、コレステリンは烧脂䶂と共に細胞を構 成する脂临成分である。したがって細胞・組織の脂澌の 变性によってコ結晶が析出してくる可能性は考えられ 
る、しかしながら著者が小さいコ結晶を追及してえられ た所見からは，コ結晶が細胞・組織の脂肪変性から生じ るといら考えを支持することはできなかった。

以上，えられた所見赽考察すれば，著者は，ヒトの耳 に生じるコ肉芽稙内のコ結晶付，血行障碍に上って生じ た血液成分より生じたことを電顕的に初めて明らかにし えたと考える。

\section{結語}

コ肉芽腫内のコ結晶由来を知る目的で，12才より56才 にわたる男・女10人，11耳の乳突腔よりコ肉芽腫を手術 的に採取, Millonig 法によるオスミック酸固定, アセ トン上昇列の脱水，エポン包埋を行ない，コ・クレフト 执よびその周辺を電影的に観察し，以下の所見をえた。

1）発生初期上考えられる小さいコ・クレフトが多数 の変性赤血球, 変性血液細胞, および食細胞に接して存 在した，胞体内に多数の phagosome, residual body. myelin figure を有する食細胞の内部に小さいコ・クレ フトを認めた。

2）コ・クレフトの周囲に泡沫細胞がしばしばあらう れる。この細胞は食細胞の一つであると考えた。

3）赤血球，および血液細胞由来とみられる変性細胞 が，光顕ではコ・クレフトとして識別しえない小さなコ ・クレフトと密接して常在した。

4）コ・クレフトの周辺の血管は，しばしば血烃像， および血流停滞像を示した。

5）これらの所見は，血行障碍をおこした血管の血液 成分よりコ・結晶が生じることを強く示唆しいてると考 えた。

\section{引用 文 献}

1) Shambaugh, G.E.: Blue drum membrane. Arch. Otolaryng., 10, 238, 1929.4) より引用す.

2) $O^{\prime}$ Donnell, J. H.: "Blue drum" or Idiopathic hemotympanum in children. Brit. Med. Jour., 2, 86, 1941.

3) Johnston, W.R.: The problem of the blue eardrum. Idiopathic hemotympanum. Laryngoscope, 63. 1096, 1953.

4) Sheehy, J.L., Mckibben, B.G.: Idiopathic hemotympanum. Review of the literature and report of three cases. Laryngoscope, 66, 1291, 1956. 5) Singer, L.: Ueber entzündliche Erkrankungen des Mittelohres und der pneumatischen Hohlräume des Schlafenbeines. Z. Hals-, Nasen-u. Ohrenheilk., 32. 130, 1933.

6) Friedmann, L.: Epidermoid cholesteatoma and cholesterol granuloma. Expri- mental and human. Annals of Otology and Laryngology, 68, 57, 1959.

7) Tumarkin, A.: Attic cholesteatosis. Jour. Laryngol. and Otol., 72, 610, 1958.

8) Riiedi, L. : Cholesteatosis of the attic. Jour. Laryngol. and Otol., 72, 610, 1958.

9) Ranger, $D_{\text {. : }}$ Idiopathic haemotympanum. Jour. Laryngol and Otol., 63, 672, 1949.

10) Hybášek, J. and Hybášek, I. : Etiopathogenesis of the socalled idiopathic haemo. tympanum and its relation to morphogenesis of an adhaesive process. Acta Oto-Laryng., Stockholm, 53, 429, 1961 . 11) Hybášek, I. : Über das Cholesterolgranulom bei Mittelohrentzündungen. Mschr. Ohr. hk., Wien, 99, 359, 1965. 12）東年：医学生物 学用電子顕微鏡学, 文光堂, 1964.

13) Benj$a m i n, F . T$.: A method of staining epoxy section for light microscopy. J. Ultrastructure Research, 5, 343, 1961. 14) Mannase：6) と15) 上り引用す。

15) Dota et al: Cholesterol granuloma. Annals of Otology and Laryngology, 72, 346, $1963 . \quad 16)$,t 田武正：所謂コレステリン内芽腫路よび耳真珠腫につい て. 日耳聨., 69, 447, 1966.13 17) Adner, C. A., Idiopathic haematotympanum and mastoiditis nigra. Acta Oto-Laryng., Stockholm, 52, 157, 1960. Cook, R, P. : Cholesterol. Academic press Inc., 1958. 19) Birrell, J.F. : Black cellular cholesteatosis in childhood. Jour. Laryngol. and Otol., 70, 260, 1965.

20) Lichtenstein: Xantosis 及び cholesterosis 大脳鎌内中皮細胞腫。脳之神経。4,16, 1962.

M. Shimoda: Personal communication.

22) $T$. Ito and T. Hoshino: Light and electoron microscopic observation on the vascular pattern of the thymus of the mouse. Arch. histol. jap., 27, 351, 1966.

23）大山泰雄：础脈病变の電子湿微鏡的研究，こと飞動

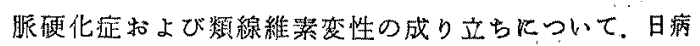
会誌. 51，146，1957. 24）綿貫勤他：Wolman 病. 最新医学. 22, 146, 1957, 25) Still, W.J.S. and $O^{\prime} N e u l, R . M$. : Electron microscopic study of experimental atherosclerosis in rat. Amer. J. Path., 40, 21,

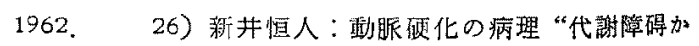
らみた成り立ちとくに初期像化ついて”日病会誌 51 , $290,1962$.

稿を䅂るにあたり，御腎切なる御指導と御校閲を睗か 
写真 1

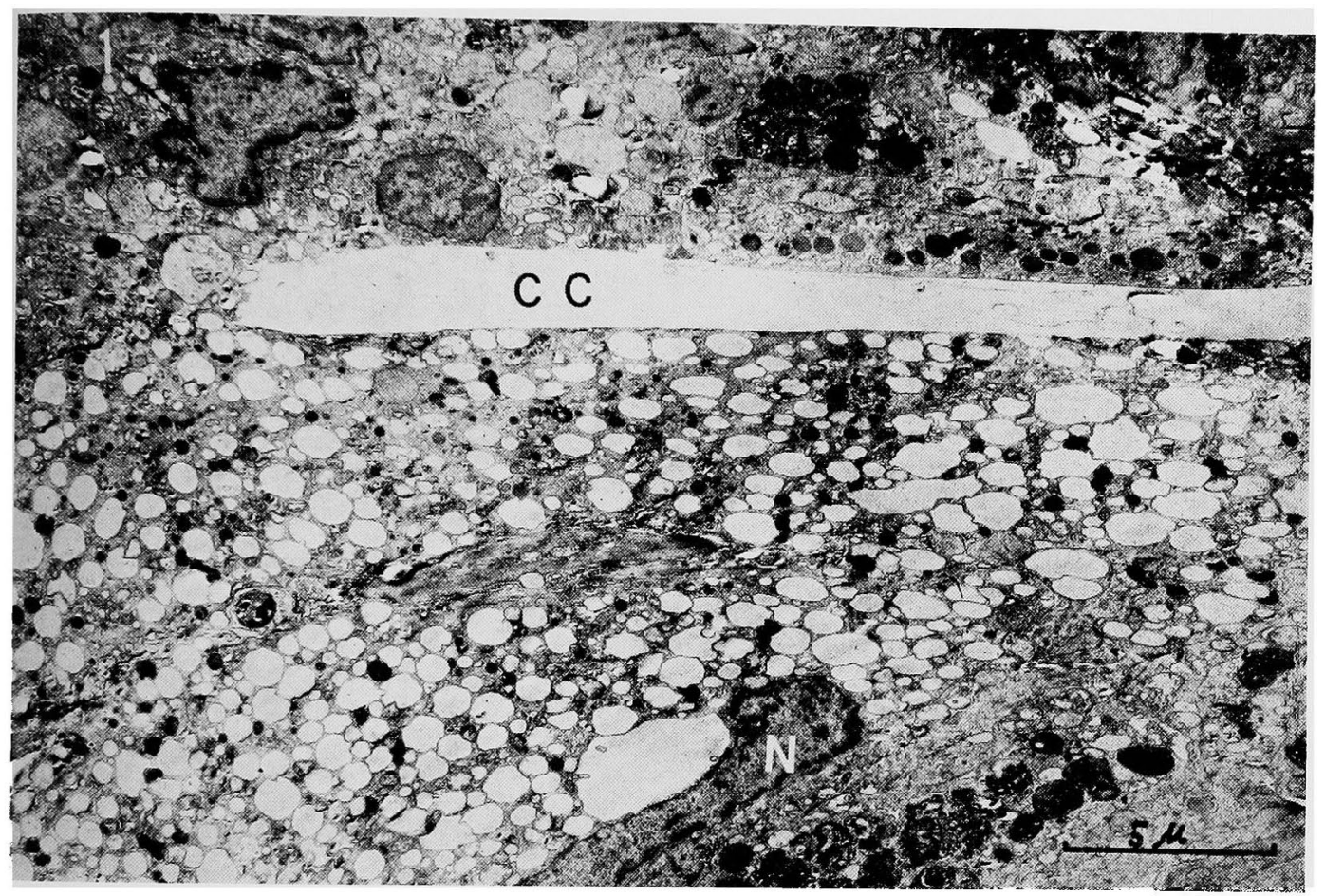

写真 2

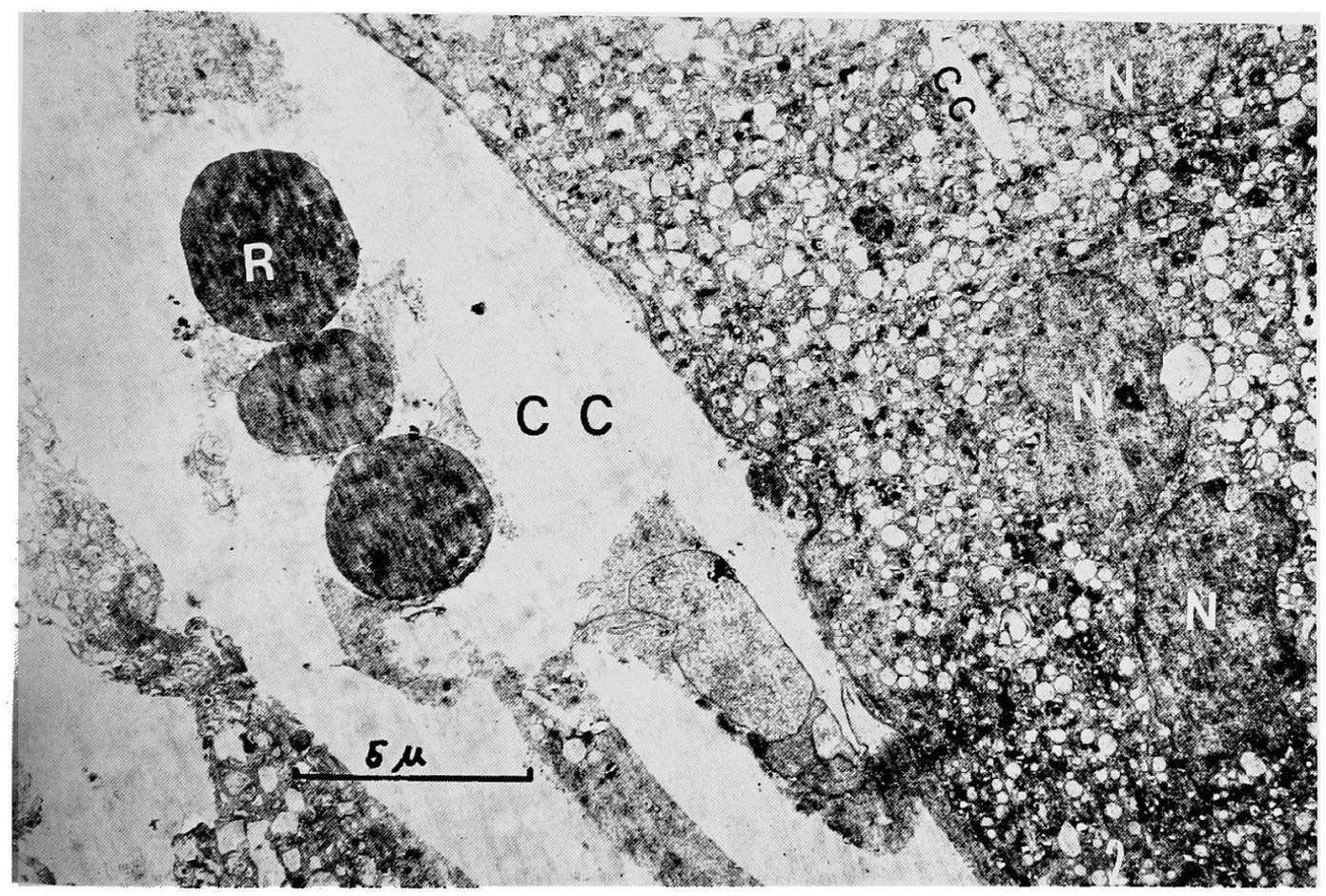


坂本毅論文付図（II）

写真 3

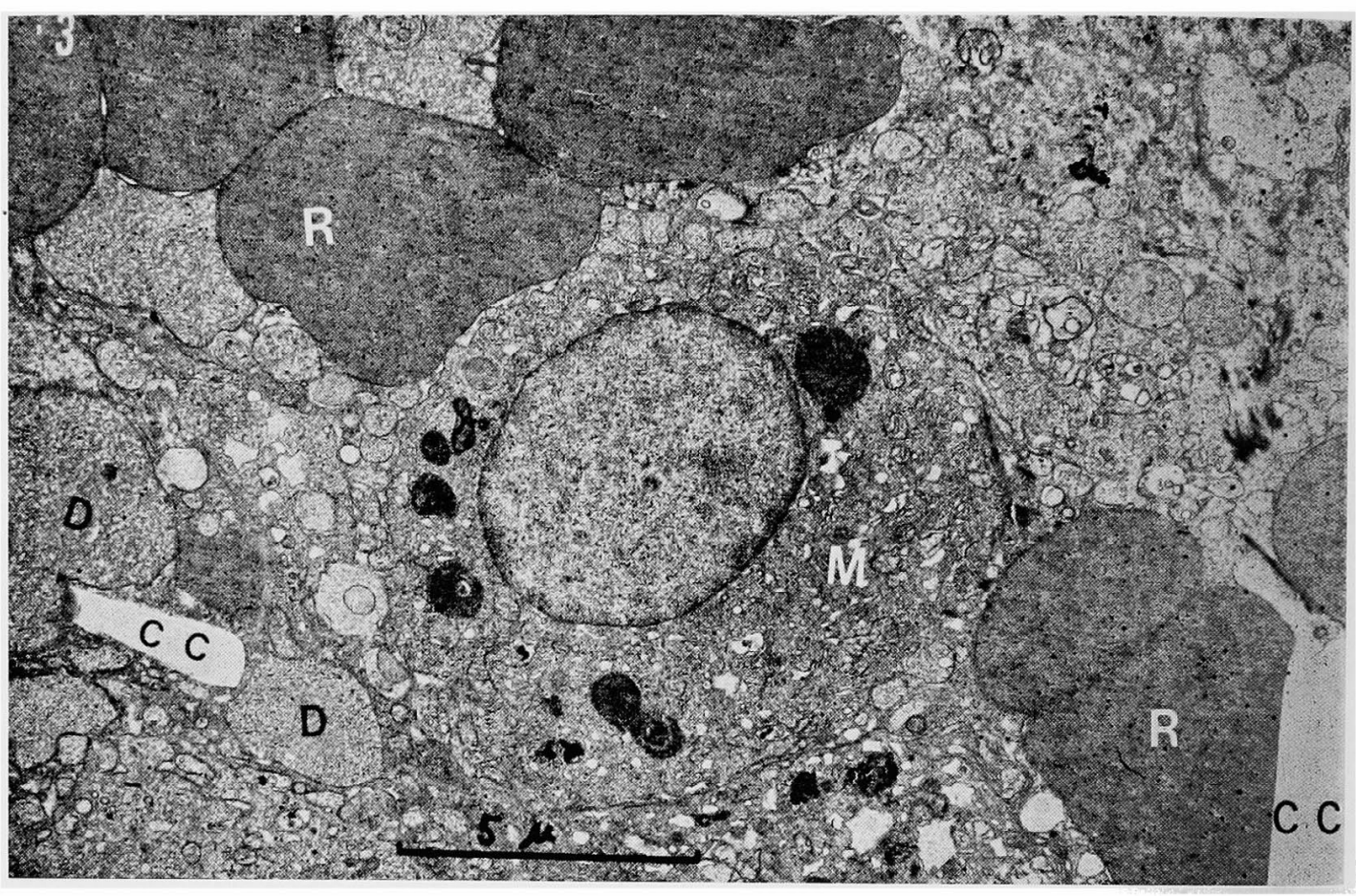

写真 4

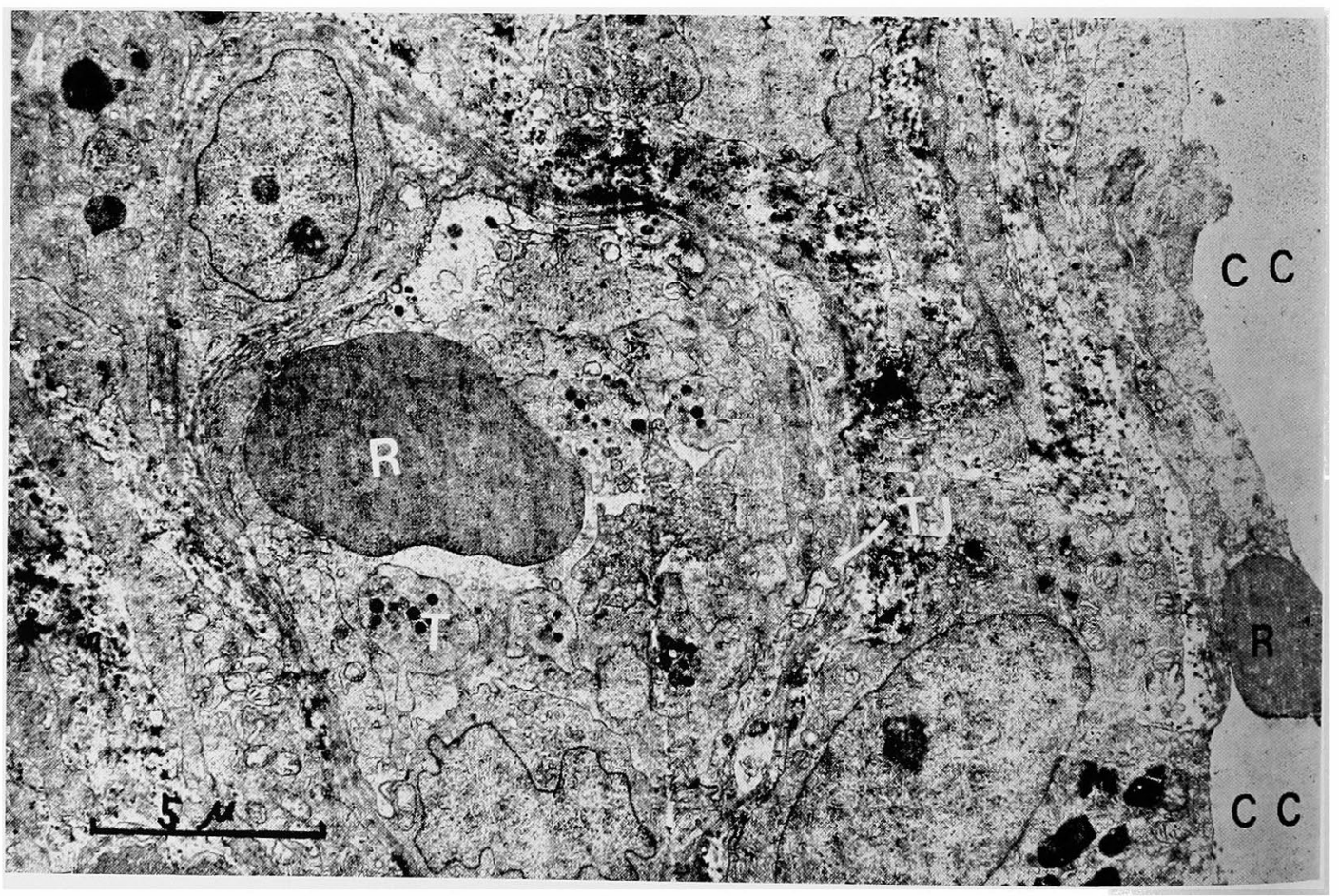


坂本毅論文付図（III）

写真 5

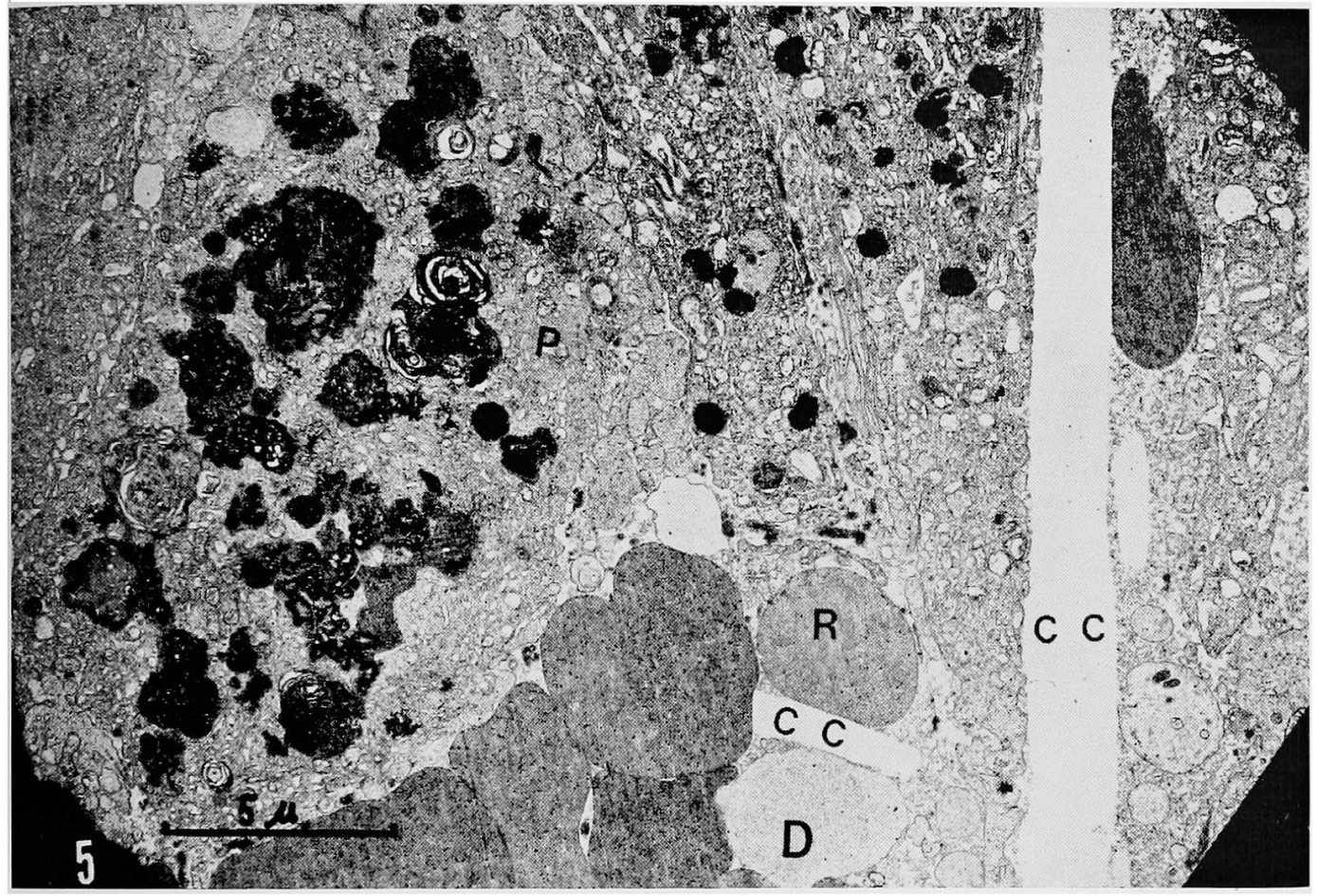

写真 6

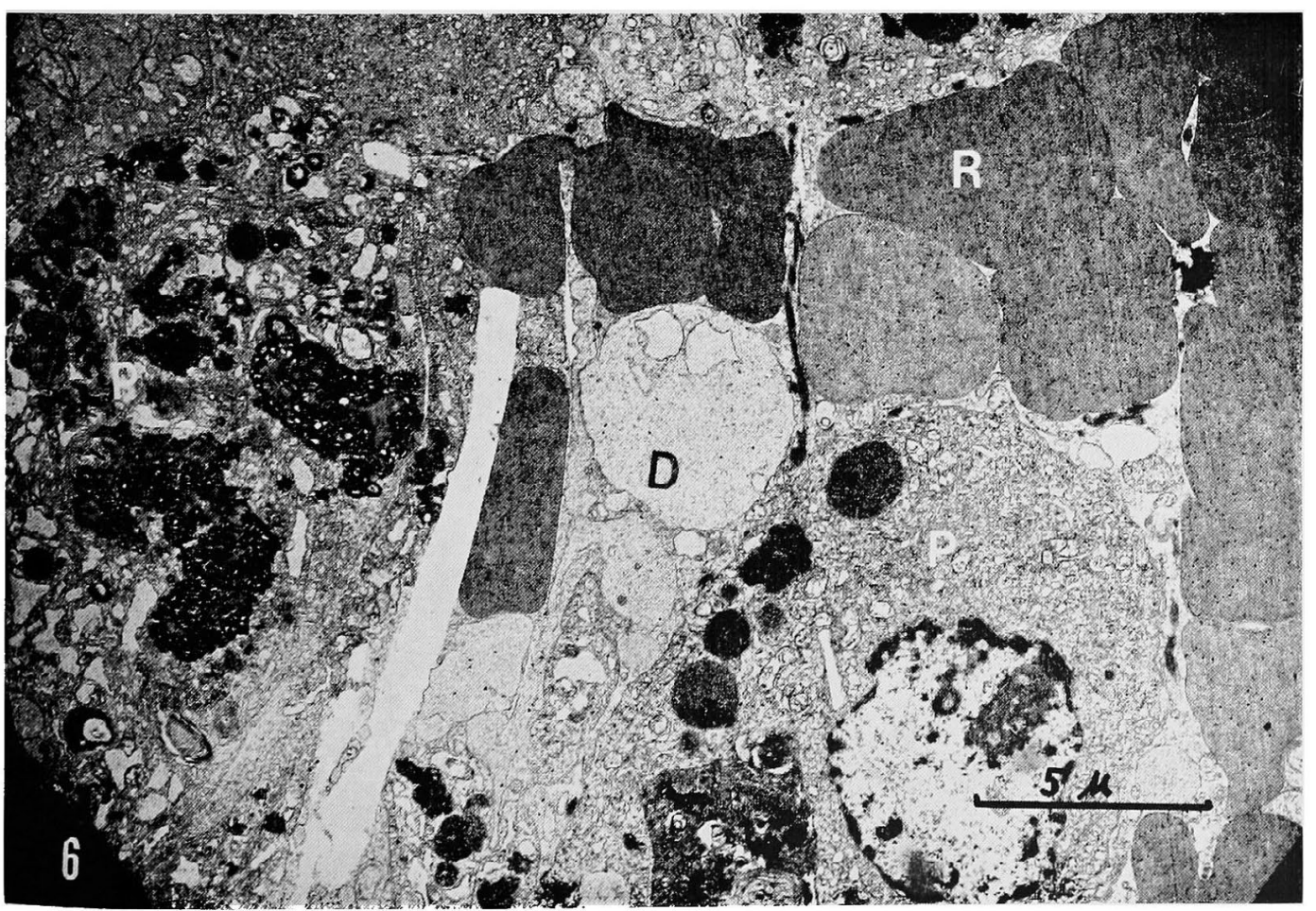


坂本毅論文付図 (IV)

写真 7

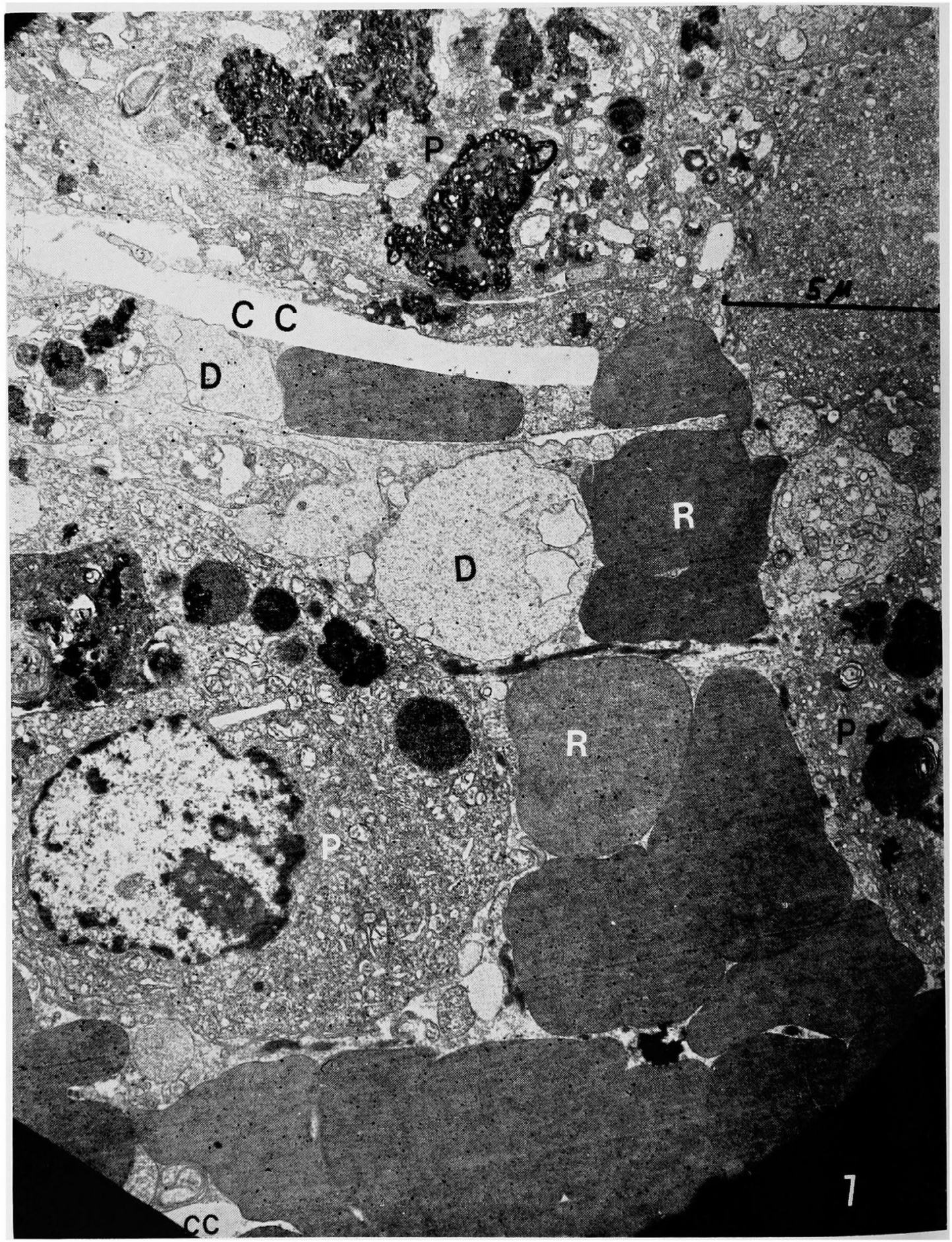


坂本毅論文付図 (V)

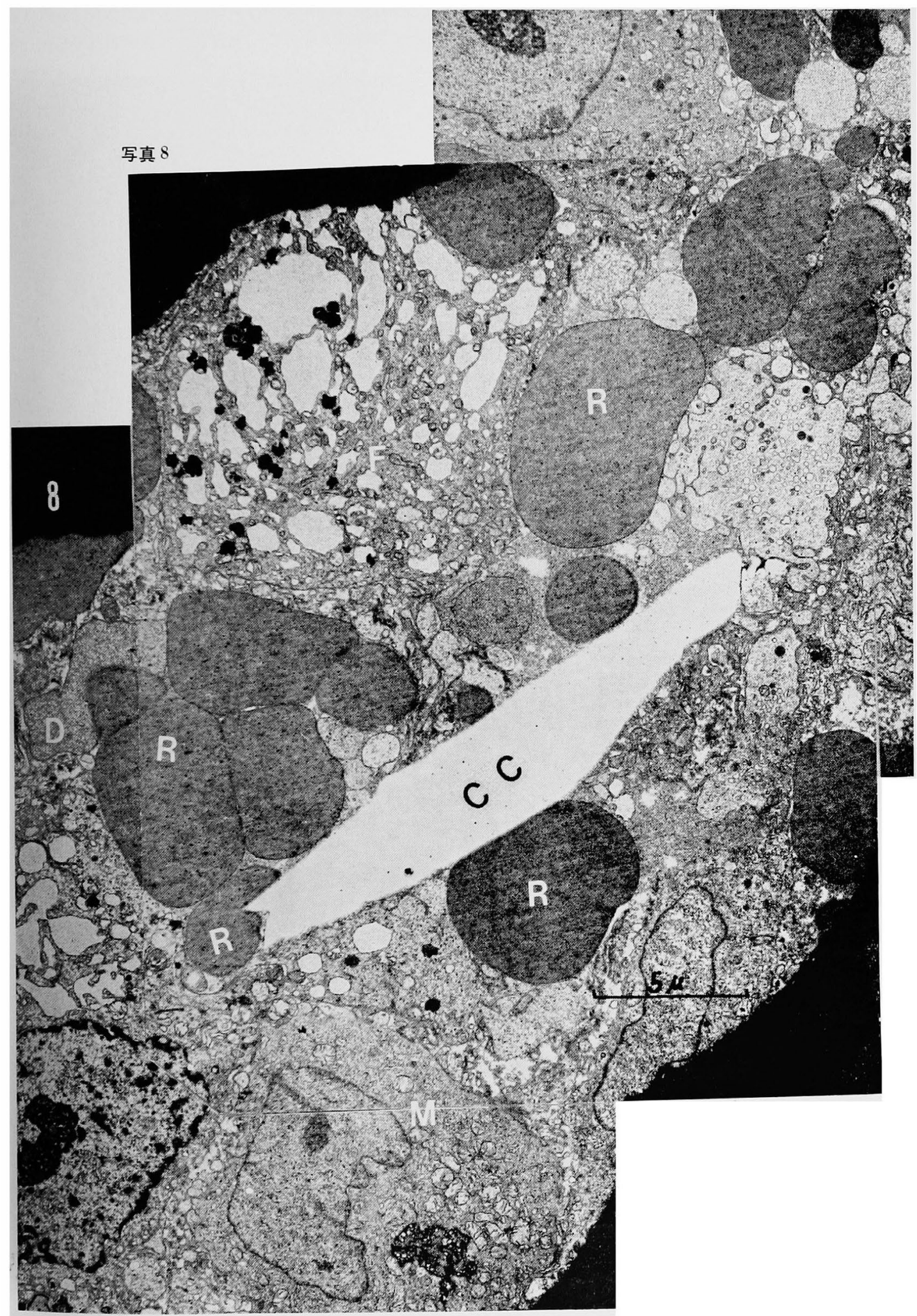


坂本毅論文付図 (VI)

軍真 9

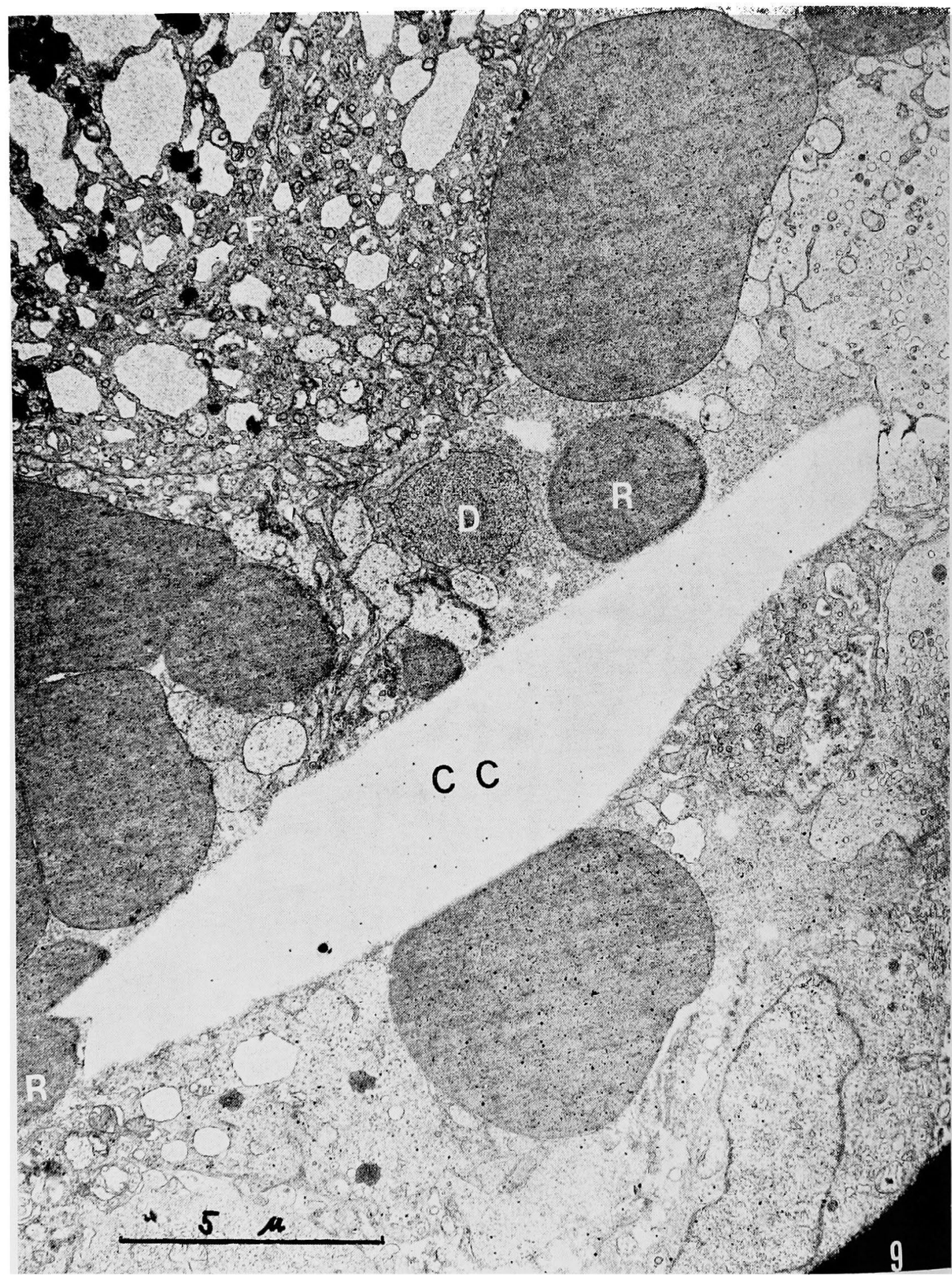


った恩師平野新治教授，第三解剖学教室の伊藤隆教授， 第二病理学教室の恩村雄太教授，ならびに終始御指導々 御鞭恶をいただいた耳费咽喉科教室の土田武正助教授、 第三解剖学数室の星野洸助教授，国立札蝟病院中央娭查 科長の下田晶久医学博士に深甚なる謝意を㥭げる。

\section{附图説明}

[略字説明]

$\mathrm{CC}$ : Cholesterine cleft

$\mathrm{D}:$ D-cell

$\mathrm{R}:$ Red blood cell

$P$ : Phagocyte

$\mathrm{F}:$ Foam cell

M : Monocyte

$T:$ Thrombocyte

$\mathrm{N}:$ Nucleus

$\mathrm{TJ}$ : Tight junction

\section{写真 1}

コ・クレフト(CC) K接する泡沫細胞（foam cell）を 示す.コ・クレフト内に瞙樣構造が断裂邀離して存在す る。これはコ結晶が溶出する榞，結晶と接する細胞の細 胞膜が断裂移動したるのと考占られる。

泡沫細胞の核 (N) は辺緑に压排されている.空胞は 胸体内を殆んど充満している。空胞は限界膜を有し，円 形に近いすのが多く, 大小は不同て，直径 $0.2 \mu$ から $4 \mu$ にわたって存在する．空胞の内部飞電子密度の低い系状 の構造が存在する。空胞間に electron dense な制粒が散 在す万. $4600 \times$

\section{写真 2}

CCに接する巨細胞を示す。 3 個の核が細胞膜の境界 むしに並列する.胞体内にに無数の抁張したendoplasmic reticulum が充满してみられる。これは泡沫細胞に移行 ナる像を示している，写真の左にCCに仕さまれた の赤血㹬（R）がある.ここにはコレステリン結晶溶出 の祭，CCにはさまれた細胞質が移動した像がみられる。 $5000 \times$

\section{写真 3}

D細胞にはさまれた小さいCCが存在する，CCの一端 がD細胞にくいこんだ形となり，その接する境界に electron dense な zone がみられる。隣接する大型の細胞 は単球と考えられる，視野の周团に多数の亦血球が存在 ナるか，その電子密度には差が生している，写真右下の
CC k接する亦血球は䨓子密度が低くなり，赤血球膜の 膨化とみられる像を示している。 $6400 \times$

\section{写真 4}

CC ととの周囲の血管の放化を示す。この血管は細静 脈々考之られ，管控内比《一個の赤血球，多数の程球 （T），他の血液細胞，および血獎成分がつまってみ兄 る.この血管の内皮細胞は， tight junctionを境として 隣接する 2 個の内皮に電子密度の差が生じている（矢印 で示す)．周囲の組䋐間隙の collagen 線維にはdenseな 物質の沈着をみる。 $5000 \times$

\section{军鼓 5}

細胞外に小さい CCが多数の赤血港と D細胞に囲まれ て存在する，その間吵江電子密度の低い粒子群で埋めら れている，写真右侧に大きなCC々小さいCCが存在し， これに赤血球が接している，写真中央の左側に赤血球の 十数倍の大きさの細胞が認められるが，その胞体内多 くの myelin figure, phagosome る有し食細胞とみられ ๖. $5000 x$

\section{写真 6}

細胞外に赤血球，D細胞飞国まれた CC が認められ，こ れに近接して胞体内に myelin figure, phagosome, residual bodyを有する食細胞が数個認められる。胞体内K 小さいCC を有する食細胞も認められる。 $5000 \times$

\section{写真 7}

写真 6 をやや拡大したものである．周辺に多数の赤血 球が相接してみられるが，その電子密度に盖が生してい ることがわかる。 $7000 \times$

\section{写真 8}

泡沫細胞，赤血的，単球に囲まれた多角形の CC が写 真の略々中央にみられる。 CCに接する数個の赤血球の 電子密度は低くなり，かつ赤血球膜の膨化像がみられ る、CCの一端が鋭く赤血球にくいこんだ形でみられる

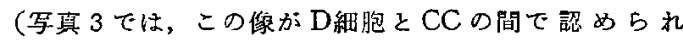
る).この写真にみられる泡沫細胞の空胞の形は不整形 そなっている。これらの細胞とCCの間隙は，電子密度 の低い微細な柆子によって埋められて放りここれは血浆 成分とみられる。 $5000 \times$

写真 9

写真 8 の拉大であり，CCの周围をとくに执大して示 した像である。 $8000 \times$

（原稿受付 昭和 42.6.20) 